\title{
Pengaruh Lingkungan Keluarga dan Fasilitas Belajar pada Prestasi Belajar IPS Siswa Ditinjau dari Motivasi Belajar
}

\author{
Laela Lutfiana Rachmah ${ }^{1}$, Sunaryanto ${ }^{2}$, Yuniastuti ${ }^{3}$ \\ ${ }^{1}$ Pendidikan Dasar-Universitas Negeri Malang \\ ${ }^{2}$ Pendidikan Akuntansi-Universitas Negeri Malang \\ ${ }^{3}$ Hukum dan Kewarganegaraan-Universitas Negeri Malang
}

\section{INFO ARTIKEL}

\section{Riwayat Artikel:}

Diterima: 22-05-2019

Disetujui: 12-09-2019

\section{Kata kunci:}

learning environment; learning facilities; social studies learning outcomes; motivation to learn, lingkungan belajar; fasilitas belajar; hasil belajar IPS; motivasi belajar

\author{
Alamat Korespondensi: \\ Laela Lutfiana Rachmah \\ Pendidikan Dasar \\ Universitas Negeri Malang \\ Jalan Semarang 5 Malang \\ E-mail: Laelalutfiana@gmail.com
}

\section{ABSTRAK}

Abstract: This research aims to examine the direct and indirect influence of family environment variables (X1), and the learning facilities (X2) as the independent variable (independent), motivation to learn ( $\mathrm{Z}$ ) as a variable intervening, and student achievement $(\mathrm{Y})$ as a variable bound (dependent). The approach uses is ex post facto with quantitative research. The research sample of 145 students who score 80-100 learning achievement of all class taken by proportionate random sampling method. Retrieving data using questionnaire instrument. The analysis technique used is the classical assumption of normality test, heteroscedasticity and multicollinearity test. The results showed; (1) there is a direct influence of family environment on student motivation with sig. $0.000<0.05$; (2) there is a direct influence of the learning facilities to students' learning motivation with sig. $0.000<0.05$; (3) there is a direct influence of family environment on learning achievement IPS; (4) there is a direct influence of student learning facilities to the student achievement IPS with sig. $0.000<0.05$; (5) there is a direct influence of students' motivation towards learning achievement IPS with sig. $0.020<0.05$; $(6)$ there is the indirect influence of family environment on learning achievement IPS with a total effect of 0.398 ; (7) the indirect effect includes IPS study on learning achievement which is viewed from student motivation to influence total 0.395 .

Abstrak: Penelitian ini bertujuan mengetahui ada tidaknya pengaruh langsung dan tidak langsung pada variabel lingkungan keluarga $\left(\mathrm{X}_{1}\right)$ dan fasilitas belajar $\left(\mathrm{X}_{2}\right)$ sebagai variable independent, motivasi belajar $(\mathrm{Z})$ sebagai variabel intervening, dan prestasi belajar siswa (Y) sebagai variabel dependent. Pendekatannya menggunakan ex post facto dengan jenis penelitian kuantitatif. Sampel penelitian sebanyak 145 siswa yang mempunyai nilai prestasi belajar 80-100 dari semua kelas yang diambil dengan metode proportionate random sampling. Pengambilan data menggunakan instrumen angket. Teknik analisis yang digunakan yakni asumsi klasik yang terdiri dari uji normalitas, uji heteroskedastisitas, dan uji multikolinearitas. Hasil penelitian menunjukkan (1) ada pengaruh langsung lingkungan keluarga pada motivasi belajar siswa dengan nilai sig. $0,000<0,05 ;(2)$ ada pengaruh langsung antara fasilitas belajar terhadap motivasi belajar siswa dengan nilai sig. $0,000<0,05$; (3) ada pengaruh langsung antara lingkungan keluarga terhadap prestasi IPS; (4) ada pengaruh langsung antara fasilitas belajar siswa terhadap prestasi IPS siswa dengan nilai sig. $0,000<0,05$; (5) ada pengaruh langsung antara motivasi belajar siswa terhadap prestasi belajar IPS dengan nilai sig. $0,020<0,05$; (6) ada pengaruh tidak langsung antara lingkungan keluarga pada prestasi belajar IPS dengan pengaruh total 0,$398 ;(7)$ ada pengaruh tidak langsung antara fasilitas belajar pada prestasi belajar IPS yang ditinjau dari motivasi belajar siswa dengan pengaruh total 0,395. 
Mata pelajaran IPS merupakan pembelajaran yang luas mencakup kehidupan masyarakat. Tujuan dari pembelajaran IPS adalah mengembangkan siswa menjadi masyarakat dengan kemampuan pengetahuan, nilai, sikap, dan keterampilan yang cukup guna terjun pada kehidupan demokrasi (Supardan, 2015). Melihat dari pentingnya tujuan pembelajaran IPS maka sudah seharusnya pendidik memperhatikan banyak faktor yang dapat meningkatkan hasil belajar/prestasi belajar IPS. Prestasi atau hasil belajar anak didik adalah hal urgen. Dikarenakan prestasi belajar merupakan output dari proses pembelajaran yang telah dilakukan. Prestasi belajar sendiri dipengaruhi banyak faktor, faktor internal diri siswa serta faktor lingkungan sekitar siswa (Suwardi, 2012). Contoh faktor internal yakni motivasi belajar dan faktor eksternal yakni lingkungan keluarga dan fasilitas belajar siswa.

Lingkungan keluarga adalah faktor yang sangat penting dalam perkembangan anak, salah satunya keberhasilan belajar anak. Hal tersebut dikarenakan lingkungan keluarga merupakan tempat utama anak belajar sejak anak lahir. Menurut (Djamarah, 2014) keluarga adalah lingkup sosial awal mula kehidupan. Dalam keluarga, setiap orang mulai mempelajari apa yang oranglain inginkan, bekerjasama, dan belajar menolong sesama. Keluarga merupakan lembaga pendidikan utama bagi anak karena dengan adanya keluarga dapat melahirkan manusia yang berkembang menjadi dewasa. Lingkungan keluarga ikut andil dalam menentukan prestasi anak di sekolah. Hal tersebut dikarenakan adanya faktor-faktor dalam lingkungan keluarga seperti parenting, hubungan sosial setiap anggota, kondisi rumah, permasalahan ekonomi, dan perhatian orangtua (Slameto, 2015). Lingkungan keluarga sendiri mempunyai dampak langsung dan tidak langsung pada prestasi belajar siswa. Lingkungan keluarga yang positif berdampak pada motivasi belajar, semakin bagus serta positif lingkungan keluarga maka semakin bagus juga motivasi belajarnya (Rachmah, Sunaryanto, \& Yuniastuti, 2019). Motivasi yang tinggi dari siswa ini juga akan memengaruhi keberhasilan belajar siswa. Didukung penelitian (Rachmah et al., 2019) disimpulkan bahwa ada dampak lingkungan keluarga pada motivasi belajar siswa. Oleh karena itu, orangtua wajib memberikan lingkungan keluarga yang bagus bagi anak guna meningkatkan prestasi anak.

Faktor motivasi menjadi faktor yang cukup urgen guna menunjang peningkatan prestasi belajar siswa, karena motivasi rendah akan memengaruhi proses belajar siswa, siswa bermotivasi rendah cenderung mempunyai kemauan rendah pula saat mempelajari sesuatu, sebaliknya siswa bermotivasi tinggi akan mempunyai kemauan dan keaktifan yang baik saat kegiatan pembelajaran. Menurut (Purwanto, 2014) seseorang akan termotivasi atau terdorong untuk berusaha menganalisis sesuatu dengan sebaik-baiknya jika mengetahui pentingnya hasil belajar. Memiliki motivasi belajar tinggi akan memaksimalkan prestasi belajar (Sardiman, 2004). Penelitian yang dilakukan oleh (Jamal, 2017) menjelaskan, semakin tinggi motivasi belajar seseorang akan semakin tinggi juga prestasinya. Didukung penelitian (Novalinda, Kantun, \& Widodo, 2017) bahwa motivasi mempunyai dampak signifikan pada output KBM siswa. Keterkaitan motivasi dengan prestasi belajar tersebut dikarenakan motivasi dipengaruhi oleh cita-cita yang dimiliki siswa, keinginan siswa, keadaan siswa, keadaan lingkungan siswa, faktor-faktor dalam belajar, dan upaya guru dalam memahirkan siswa (Dimyati \& Mudjiono, 2010). Oleh sebab itu, motivasi memiliki andil yang cukup urgen pada keberhasilan proses pembelajaran.

Fasilitas belajar merupakan faktor lainnya yang bisa memperbaiki prestasi siswa. Fasilitas belajar menurut (KBBI, 2011) yakni sarana yang digunakan guna mempermudah kegiatan belajar. Kelengkapan fasilitas belajar yang tersedia di sekolah akan memengaruhi keberhasilan belajar siswa. Sekolah yang memiliki fasilitas belajar yang bagus tentu akan lebih mudah melaksanakan pembelajaran dengan lebih baik yang nantinya akan berimbas pada tingkat prestasi siswa. Penelitian ini sejalan dengan riset oleh (Puspitasari, 2016) bahwa sarana prasarana yang dimiliki sekolah berpengaruh terhadap prestasi belajar siswa. Riset lainnya oleh (Yonitasari, 2014), memperlihatkan hasil bahwa fasilitas belajar berdampak bagus pada prestasi belajar ekonomi anak didik. Didukung pula penelitian (Rahman, 2015) bahwa fasilitas belajar mempunyai dampak pada keberhasilan prestasi siswa. Oleh karena itu, sekolah perlu memperhatikan ketersediaan sarana prasarana guna membantu ketercapaian pelaksanaan pembelajaran yang efektif.

Fasilitas belajar yang diberikan orangtua kepada anak sangat memengaruhi hasil belajarnya. Dibuktikan oleh riset (Prihatin, 2017) bahwa fasilitas belajar berdampak positif pada hasil belajar. Lingkungan keluarga dan motivasi sangat berdampak pada hasil belajar siswa. Hal ini dibuktikan oleh penelitian (Jamil \& Azra, 2014) bahwa lingkungan keluarga dan motivasi belajar siswa secara bersama-sama sangat berdampak pada hasil belajar. Lingkungan keluarga dan fasilitas belajar akan sangat menentukan hasil belajar pada anak. Sehubungan dengan hal tersebut (Mega, 2017) menyatakan bahwa ada dampak signifikan antara lingkungan keluarga dan fasilitas belajar pada hasil belajar, hal ini menunjukkan bahwa dengan lingkungan keluarga yang baik serta fasilitas belajar yang memadahi akan menyebabkan peningkatan pada hasil prestasi. Oleh karena itu, bisa dikatakan bahwa semakin baik lingkungan keluarga dan fasilitas belajar, maka semakin bagus juga prestasi yang didapatkan siswa.

Mengacu pada pentingnya faktor internal yaitu motivasi belajar dan faktor eksternal berupa lingkungan keluarga dan fasilitas belajar yang dapat memengaruhi prestasi belajar siswa, maka peneliti akan mengkaji tentang pengaruh lingkungan keluarga dan fasilitas belajar yang ditinjau dari motivasi belajar siswa di SMP Negeri 1 Ngunut kabupaten Tulungagung tahun ajaran 2018/2019. Riset yang dilakukan diharapkan dapat memperkuat teori dan hasil penelitian mengenai pengaruh faktor internal dan eksternal pada prestasi belajar sehingga dapat bermanfaat bagi guru dan orangtua siswa. 


\section{METODE}

Metode yang dipakai adalah ex post facto dengan jenis penelitian kuantitatif. Penelitian ini mempunyai tujuan menganalisis pengaruh antar variabel bebas yakni lingkungan keluarga $\left(\mathrm{X}_{1}\right)$ dan fasilitas belajar $\left(\mathrm{X}_{2}\right)$ dengan variabel terikat yakni prestasi belajar (Y), baik secara langsung ataupun tidak langsung yang ditinjau dari variabel intervening yakni motivasi belajar (Z). Teknik analisis statistik yang dipakai yakni analisis jalur (path analysis) dengan memakai korelasi, regresi, dan jalur. Desain penelitian dapat dilihat pada gambar 1.

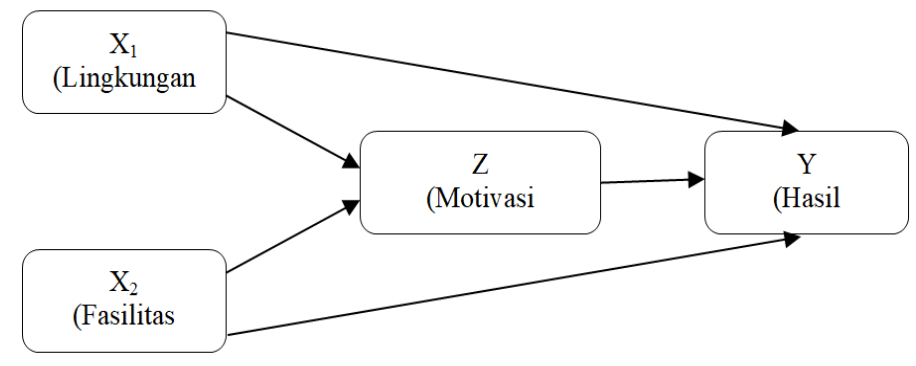

Gambar 1. Path Analysis Design

Populasi penelitiannya seluruh siswa SMP Negeri 1 Ngunut Kabupaten Tulungagung tahun ajaran 2018/2019 dengan nilai 80-100 yang berjumlah 233 siswa. Sampel yang digunakan diperoleh memakai teknik proportionate random sampling dari seluruh siswa kelas VII, VIII, dan IX SMP Negeri 1 Ngunut kabupaten Tulungagung yang berjumlah 31 kelas dan di setiap kelasnya jumlah siswa yang memiliki nilai 80-100. Penetapan jumlah sampel perkelasnya menyesuaikan dengan siswa yang memiliki nilai 80-100 untuk menghindari terjadinya perbedaan yang terlalu jauh antara jumlah sampel di setiap kelasnya. Sehingga keseluruhan sampel yang dipakai yakni 145 siswa.

Instrumen data yang dipakai yakni instrumen penelitian berupa kuesioner. Angket yang dipakai guna mengumpulkan data dari variabel fasilitas belajar dan motivasi. Sebelum dipakai dalam penelitian, terlebih dahulu dilakukan tes validitas dan reliabilitas guna mengetahui kevalidan dan konsistensi instrumen. Uji validitas memakai uji correlation, sedangkan uji reliabilitas memakai Cronbach Alpha melalui aplikasi SPSS versi 21.0. Setelah instrumen valid dan reliabel maka instrumen bisa dipakai saat penelitian. Data yang sudah diperoleh pada saat penelitian terlebih dahulu diuji dengan uji asumsi klasik yang meliputi uji normalitas, uji heteroskedastisitas, dan uji multikolinieritas.

Uji normalitas dilakukan memakai uji Kolmogorov-Smirnov dengan ketentuan apabila nilai sig. > 0,50 maka data dinyatakan normal, dan apabila nilai sig. $<0,50$, data dinyatakan tidak normal. Pengujian heteroskedastisitas yang dilakukan menggunakan ketentuan, apabila nilai sig. $>0,05$, tidak terjadi gejala heteroskedastisitas pada sampel penelitian, dan apabila nilai sig. $<0,05$, terjadi gejala heteroskedastisitas pada sampel penelitian. Pengujian terakhir yaitu uji multikolinieritas yang hasilnya diperoleh dengan melihat nilai Tolerance dan nilai Variance Inflation Faktor (VIF). Ketentuan pada nilai Tolerance yaitu jika nilai Tolerance $>0,10$, tidak terjadi multikolinieritas, dan nilai Tolerance $<0,10$ terjadi multikolinieritas, sedangkan ketentuan pada nilai VIF yaitu jika nilai VIF $\leq 10,00$, tidak terjadi multikolinearitas diantara variabel independen dan jika VIF $>10,00$, bisa dikatakan terjadi multikolinearitas diantara variabel independen. Tahap terakhir setelah dilakukan uji asumsi klasik maka dilaksanakan tahap pengujian hipotesis. Pada penelitian ini digunakan uji analisis jalur melalui aplikasi SPSS versi 21.0.

\section{HASIL DAN PEMBAHASAN}

Penelitian dilaksanakan di SMP Negeri 1 Ngunut kabupaten Tulungagung tahun ajaran 2018/2019 tanggal 6-30 Nopember 2018 dengan subjek penelitian dari kelas VII, VIII, dan IX yang memiliki nilai 80-100 berjumlah 233 siswa. Sebelum dilaksanakn pengujian hipotesis, terlebih dahulu dilaksanakan uji validitas, reliabilitas serta uji asumsi klasik terhadap sampel penelitian yang digunakan. Berdasarkan hasil uji validitas menggunakan uji correlation terhadap instrumen fasilitas belajar, dan instrumen motivasi belajar dinyatakan valid dikarenakan diperoleh nilai $\mathrm{r}_{\text {hitung }}>\mathrm{r}_{\text {tabel }}$. Berdasarkan uji reliabilitas menggunakan Cronbach Alpha terhadap ketiga instrumen diperoleh nilai hitung sebesar 0.630 (instrumen lingkungan keluarga), sebesar 0,701 (instrumen fasilitas belajar), dan 0,686 (motivasi belajar). Dikarenakan nilai hitung sebesar 0,701 dan 0,686 > $\mathrm{r}_{\text {tabel }}$ sebesar 0,163 maka instrumen dinyatakan reliabel.

Setelah instrumen dikatakan valid dan reliabel, maka perlu dilakukan tahap selanjutnya yakni uji asumsi klasik. Uji asumsi klasik ini memakai tiga jenis pengujian yaitu uji normalitas menggunakan uji Kolmogorov-Smirnov, uji heteroskedastisitas, dan uji multikolinieritas. Hasil yang diperoleh dari uji normalitas yaitu data fasilitas belajar sampel memperoleh nilai sig. sebesar 0,822 dan motivasi belajar memperoleh nilai sig. sebesar 0,413 . Berdasar ketentuan yang telah ditetapkan karena nilai sig. 0,822 dan 0,413 > 0,05 maka instrumen dinyatakan normal. Pengujian kedua yaitu uji heteroskedastisitas. Berdasarkan hasil pengujian 
diperoleh pola yang jelas serta titik-titik menyebar di atas dan di bawah angka 0 pada sumbu Y maka disimpulkan bahwa tidak terjadi gejala heteroskedastisitas pada sampel penelitian. Pola yang diperoleh tertera pada gambar 2 .

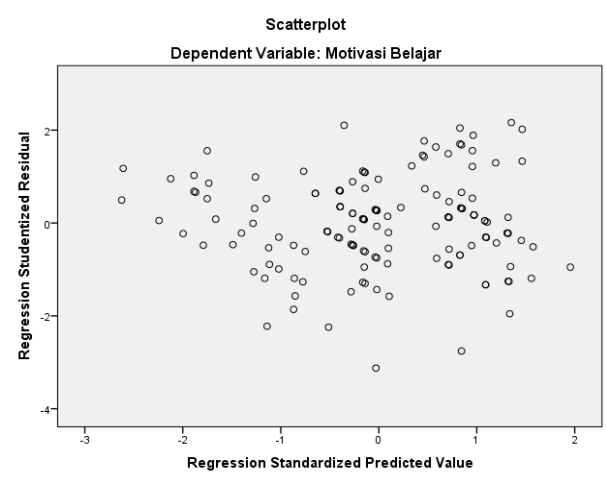

Sumber: data olahan peneliti (2019)

\section{Gambar 2. Uji Heteroskedastisitas}

Uji asumsi klasik yang terakhir yaitu uji multikolinieritas. Ketentuan pada pengujian ini yakni apabila nilai Tolerance > 0,10 , tidak terjadi multikolinieritas, dan apabila Tolerance $<0,10$, terjadi multikolinieritas. Berdasarkan pengujian yang dilakukan dengan uji linieritas dengan taraf sig. 0,05 didapatkan hasil seperti yang tertera pada tabel 1 .

Tabel 1. Hasil Uji Multikolinieritas

\begin{tabular}{ccccccc}
\hline \multirow{2}{*}{ No. } & Pengaruh & \multicolumn{2}{c}{ Linearity } & \multicolumn{2}{c}{ Deviation from Linearity } & \multirow{2}{*}{ Keputusan } \\
\cline { 3 - 6 } & & F & Sig & F & Sig & \\
\hline 1 & $\mathrm{X} 1-\mathrm{Z}$ & 145.545 & .000 & 1.977 & .017 & Linier \\
2 & $\mathrm{X} 2-\mathrm{Z}$ & 157.516 & .000 & 1.423 & .120 & Linier \\
3 & $\mathrm{X} 1-\mathrm{Y}$ & 170.717 & .000 & 3.101 & .000 & Linier \\
4 & $\mathrm{X} 2-\mathrm{Y}$ & 147.549 & .000 & 1.577 & .066 & Linier \\
5 & $\mathrm{Z}-\mathrm{Y}$ & 99.773 & .000 & .917 & .563 & Linier \\
\hline
\end{tabular}

Berdasarkan pada tabel 1 diketahui bahwa hasil uji linieritas pada model analisis jalur (analisis path) antara fasilitas lingkungan belajar, motivasi belajar, dan prestasi siswa did Linearity kurang daatkan nilai sig. pada linieritas kurangdari 0,05 (p $<0,05)$ dan nilai sig. linieritas dari deviasi lebih dari 0,05 ( $\mathrm{p}>0,05)$. Berdasarkan hasil dari ketiga pengujian maka bisa dikatakan bahwa sampel yang dalam digunakan dalam telah memenuhi syarat uji asumsi klasik dan dapat digunakan dalam kegiatan penelitian kuantitatif parametrik. Setelah sampel dinyatakan memenuhi uji asumsi klasik maka dilakukan pengujian terhadap sampel guna mengetahui pengaruh langsung fasilitas belajar pada prestasi belajar siswa, dan pengaruh tidak langsung fasilitas belajar pada prestasi belajar yang ditinjau dari motivasi belajar siswa.

Kegiatan pengujian dilakukan tanggal 6-30 Nopember 2018. Pengujian hipotesis yang dipakai yakni path analysis. Tujuan pengujian ini adalah untuk menguji besarnya konstribusi pengaruh langsung dan tidak langsung dari variabel lingkungan belajar siswa $\left(\mathrm{X}_{1}\right)$, fasilitas belajar $\left(\mathrm{X}_{2}\right)$, motivasi belajar $(\mathrm{Z})$, dan hasil belajar $(\mathrm{Y})$. Sebelum melakukan pengujian secara individual, langkah yang utama dilakukan adalah menghitung koefisien jalur model 1 dan 2 menggunakan uji regression. Jika syarat pengujian individual sudah terpenuhi maka pengujian secara individual dapat dilaksanakan. Berikut ini penjabaran hasil pengujian hipotesis.

\section{Menghitung Koefisien Jalur Model 1}

Tabel 2. Model Summary

\begin{tabular}{ccccc}
\hline Model & R & R Square & Adjusted R Square & Std. Error of the Estimate \\
\hline 1 & $.749^{\mathrm{a}}$ & .561 & .555 & 2.94871 \\
\hline \multicolumn{5}{c}{$\begin{array}{c}\text { a. Predictors: (Constant), Fasilitas Belajar } \\
\text { b. Dependent Variabel: Motivasi Belajar }\end{array}$} \\
\hline
\end{tabular}


Tabel 3. ANOVA ${ }^{\mathrm{a}}$

\begin{tabular}{|c|c|c|c|c|c|c|}
\hline & Model & Sum of Squares & df & Mean Square & $\mathbf{F}$ & Sig. \\
\hline \multirow{3}{*}{1} & Regression & 1580.291 & 2 & 790.145 & 90.875 & $.000^{\mathrm{b}}$ \\
\hline & Residual & 1234.675 & 142 & 8.695 & & \\
\hline & Total & 2814.966 & 144 & & & \\
\hline \multicolumn{7}{|c|}{$\begin{array}{l}\text { a. Dependent Variabel: Motivasi Belajar } \\
\text { b. Predictors: (Constant), Fasilitas Belajar }\end{array}$} \\
\hline
\end{tabular}

Tabel 4. Coefficients ${ }^{\mathrm{a}}$

\begin{tabular}{|c|c|c|c|c|c|c|}
\hline & \multirow{2}{*}{ Model } & \multicolumn{2}{|c|}{ Unstandardized Coefficients } & \multirow{2}{*}{$\begin{array}{c}\text { Standardized Coefficients } \\
\text { Beta }\end{array}$} & \multirow{2}{*}{$\mathbf{t}$} & \multirow{2}{*}{ Sig. } \\
\hline & & $\mathbf{B}$ & Std. Error & & & \\
\hline \multirow{3}{*}{1} & (Constant) & 13.853 & 4.825 & & 2.871 & .005 \\
\hline & Lingkungan Keluarga & .394 & .096 & .351 & 4.115 & .000 \\
\hline & Fasilitas Belajar & .421 & .080 & .447 & 5.229 & .000 \\
\hline
\end{tabular}

Uji secara keseluruhan ditunjukkan pada tabel 4. Berdasarkan pada tabel 2 didapatkan nilai $R_{\text {square }}=0,561$ dan pada tabel 3 didapatkan nilai $\mathrm{F}=90,875$ dengan nilai sig. $=0,000$, berdasarkan hipotesis yang telah dirumuskan dikarenakan nilai sig $<0,05$ Sehingga bisa dikatakan bahwa $\mathrm{H}_{0}$ di tolak dan $\mathrm{H}_{\mathrm{a}}$ diterima. Dengan Demikian, dapat dikatakan fasilitas belajar secara signifikan berpengaruh terhadap motivasi belajar siswa.

\section{Pengujian Secara Individual [ $\left(\mathrm{X}_{1}\right.$ terhadap $\left.\mathrm{Z}\right)$ dan $\left(\mathrm{X}_{2}\right.$ terhadap Z)] Model 1 Pengaruh Lingkungan Keluarga terhadap Motivasi Belajar}

Pengujian secara terpisah ditunjukkan oleh tabel 4 Coefficients, bahwa hasil koefisiensi jalur $\beta_{1}=0,351$. Pada Tabel 4 Coefficients terlihat bahwa pada kolom Sig diperoeh nilai Sig. = 0,000. Disebabkan nilai Sig. 0,000 lebih kecil dari nilai sig. 0,05 atau 0,05 >0,000, maka $\mathrm{H}_{0}$ ditolak dan $\mathrm{H}_{\mathrm{a}}$ diterima sehingga koefisien analisis jalur signifikan. Sehingga, lingkungan keluarga berpengaruh pada motivasi belajar. Hasil penelitian ini sejalan dengan Slameto (2015: 60) yang menyatakan bahwa lingkungan keluarga dapat memengaruhi belajar siswa. Sebagai orangtua harus bisa memberikan parenting sebaik mungkin, memberikan perhatian, melengkapi kebutuhan belajar anak, memberikan hubungan yang baik antara anak dan lingkungan keluarga, menyediakan suasana rumah yang teratur. Kenyamanan kondisi rumah akan menjadikan anak mempunyai keinginan belajar dan memunculkan motivasi belajar anak ketika dirumah.

\section{Pengaruh Fasilitas Belajar terhadap Motivasi Belajar}

Pengujian secara terpisah ditunjukkan pada tabel 4 Coefficients, didapatkan hasil koefisiensi jalur $\beta_{2}=0,447$. Berdasarkan tabel 4 Coefficients bisa dilihat bahwa pada kolom sig. diperoeh nilai Sig. 0,000. Sesuai norma keputusan jika nilai Sig. $0,05>0,000, \mathrm{H}_{0}$ ditolak dan $\mathrm{H}_{\mathrm{a}}$ diterima dan koefisien analisis jalur signifikan. Sehingga, fasilitas belajar berpengaruh pada motivasi belajar. Kerangka hubungan kausal empiris antara $\mathrm{X}_{1}$ dan $\mathrm{X}_{2}$ terhadap $\mathrm{Z}$ bisa dibuat melalui persamaan struktural model 1 sebagai berikut.

Struktur Model 1:

$\mathrm{Z}=\beta_{2}+\varepsilon_{1}$

$\mathrm{Z}=0,447+0,439$

Nilai $\mathrm{R}_{\text {square }}$ tertera pada tabel 4 Model Summary ${ }^{b}$. Guna mendapatkan nilai $\varepsilon_{1}$ (variabel sisa) dicari dengan rumus berikut.

$\varepsilon_{1}=1-R_{\text {square }}=1-0,561=0,439$. Dapat dilihat pada gambar 3 .

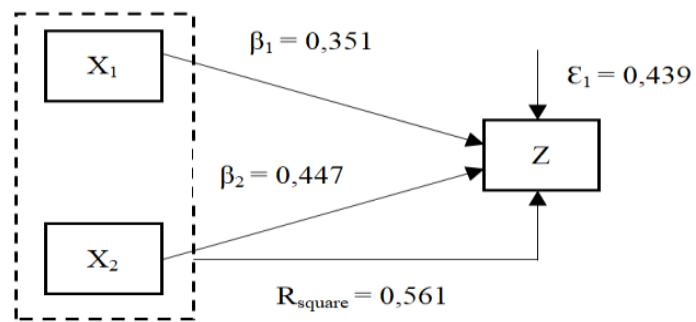

Gambar 3. Diagram Jalur Kausal Empiris $X_{1}$ dan $X_{2}$ terhadap Z Model 1 
Berdasarkan gambar 3 koefisien jalur model 1 diketahui besar koefisien jalur $\beta_{1}=0,351, \beta_{2}=0,447, \varepsilon_{1}=0,439$, dan besar nilai $R_{\text {square }}=0,561$. Hasil penelitian ini diperkuat oleh pendapat (Bafadal, 2008) fasilitas belajar adalah semua hal yang bisa membantu dan memperlancar siswa saat belajar. Seorang siswa diharapkan mampu lebih giat dalam belajar ketika fasilitas belajarnya terpenuhi. Dengan kelengkapan fasilitas belajar, siswa bias termotivasi untuk rajin belajar. Didukung penelitian (Mega, 2017) menunjukkan ada dampak signifikan fasilitas belajar pada motivasi belajar siswa. Pendapat lain disampaikan oleh (Cynthia, Martono, \& Indriayu, 2016) menyebutkan bahwa ada pengaruh antara fasilitas belajar pada motivasi belajar.

\section{Menghitung Koefisien Jalur Model 2}

Tabel 5. Model Summary ${ }^{b}$

\begin{tabular}{lcccc}
\hline Model & R & R Square & Adjusted R Square & Std. Error of the Estimate \\
\hline 1 & $.756^{\text {a }}$ & .571 & .562 & 2.45795 \\
\hline a. Predictors: (Constant), Motivasi Belajar, Fasilitas Belajar & \\
b. Dependent Variabel: Hasil Belajar & & \\
\hline
\end{tabular}

Tabel 6. ANOVA ${ }^{\mathrm{a}}$

\begin{tabular}{llccccc}
\hline & Model & Sum of Squares & df & Mean Square & F & Sig. \\
\hline \multirow{2}{*}{1} & Regression & 1136.116 & 3 & 378.705 & 62.684 & $.000^{\mathrm{b}}$ \\
& Residual & 851.857 & 141 & 6.042 & & \\
& Total & 1987.972 & 144 & & & \\
\hline
\end{tabular}

a. Dependent Variabel: Hasil Belajar

b. Predictors: (Constant), Motivasi Belajar, Fasilitas Belajar

Tabel 7 Coefficients ${ }^{a}$

\begin{tabular}{llccccc}
\hline \multirow{2}{*}{ Model } & \multicolumn{2}{c}{$\begin{array}{c}\text { Unstandardized } \\
\text { Coefficients }\end{array}$} & $\begin{array}{c}\text { Standardized } \\
\text { Coefficients }\end{array}$ & t & Sig. \\
\cline { 2 - 5 } & B & Std. Error & Beta & & \\
\hline \multirow{2}{*}{1} & (Constant) & 28.962 & 4.137 & .330 & 7.000 & .000 \\
& Lingkungan Keluarga & .311 & .084 & .308 & 3.682 & .000 \\
& Fasilitas Belajar & .244 & .073 & .195 & 3.332 & .001 \\
& Motivasi Belajar & .164 & .070 & & 2.346 & .020 \\
\hline
\end{tabular}

Uji secara keseluruhan tertera di tabel 7 Anova. Berdasarkan pada tabel 5 didapatkan nilai $R_{\text {square }}=0,571$ dan pada tabel 6 Anova didapatkan nilai $\mathrm{F}=62,684$ dengan nilai sig. $=0,000$, disebabkan nilai sig $<0,05, \mathrm{H}_{0}$ ditolak dan $\mathrm{H}_{\mathrm{a}}$ diterima. Sehingga pengujian terpisah bisa dilaksanakan.

1. Pengujian secara Individual [ $\left(\mathrm{X}_{1}\right.$ terhadap $\left.\mathrm{Y}\right),\left(\mathrm{X}_{2}\right.$ terhadap $\left.\mathrm{Y}\right)$, dan $(\mathrm{Z}$ terhadap $\left.\mathrm{Y})\right]$ Model 2

a. Pengaruh lingkungan keluarga terhadap hasil belajar

Pengujian secara terpisah tertera di tabel 7 Coefficients, bahwa hasil koefisien jalur $\beta_{3}=0,330$. Uji signifikansi analisis jalur dicari dengan membandingkan nilai sig. 0,05 dengan nilai probabilitas Sig 0,000. Pada tabel 7 Coefficients diketahui pada kolom Sig. (signifikan), diperoleh nilai Sig. 0,000. Berdasarkan nilai Sig. 0,05<0,000, $\mathrm{H}_{0}$ ditolak dan $\mathrm{H}_{\mathrm{a}}$ diterima dan koefisien analisis jalur signifikan. Sehingga, lingkungan keluarga berpengaruh pada prestasi belajar.

Adanya pengaruh lingkungan keluarga pada prestasi belajar siswa dikarenakan keluarga merupakan tempat pertama yang mengajarkan segala hal kepada anak dimulai dari cara berperilaku sampai upaya dalam mencapai keberhasilan dalam belajar. Hal tersebut sejalan dengan pendapat (Rohman \& Lamsuri, 2009) menjelaskan bahwa lingkungan keluarga mempunyai fungsi pendidikan yakni mengatur pendidikan anak sejak kecil, oleh karena itu anak bisa berkembang dengan cerdas. Didukung oleh penelitian (Sugiyanto \& Sos, 2015) bahwa terdapat dampak yang tinggi antara lingkungan keluarga pada hasil belajar. Pendapat lain juga disampaikan oleh (Jamil \& Azra, 2014) yang menjelaskan bahwa terdapat dampak signifikan antara lingkungan keluarga pada hasil belajar. Dengan demikian semakin nyaman, tenang, dan harmonis lingkungan keluarga seorang siswa, maka akan berdampak pada hasil belajar yang maksimal. Untuk itu, upaya memaksimalkan hasil belajar siswa merupakan tanggung jawab dari orangtua. 
b. Pengaruh fasilitas belajar terhadap hasil belajar

Pengujian secara terpisah tertera di tabel 7 Coefficients, bahwa hasil koefisien jalur $\beta_{4}=0,308$. Pada Tabel 7 Coefficients terlihat bahwa pada kolom Sig. diperoleh nilai Sig. 0,001. Berdasarkan nilai Sig. 0,05<0,001, $\mathrm{H}_{0}$ ditolak dan $\mathrm{H}_{\mathrm{a}}$ diterima dan koefisien analisis jalur signifikan. Sehingga, fasilitas belajar berpengaruh pada prestasi belajar.

Kelengkapan fasilitas akan memiliki dampak positif bagi siswa dikarenakan banyak media maupun sumber belajar yang dapat membantu siswa untuk belajar. Riset ini sesuai dengan riset oleh (Prihatin, 2017) dengan hasil yakni ada dampak signifikan antara fasilitas belajar baik di rumah ataupun di sekolah, gaya belajar, dan minat belajar terhadap hasil belajar. Pendapat lain juga disampaikan oleh (Sari, 2005) yang menyatakan terdapat dampak yang tinggi antara fasilitas belajar pada hasil belajar.

c. Pengaruh motivasi belajar terhadap hasil belajar

Pengujian secara terpisah tertera di tabel 7 Coefficients, bahwa hasil koefisien jalur $\beta_{5}=0,195$. Pada tabel 7 Coefficients terlihat bahwa pada kolom Sig. (signifikan), diperoleh nilai Sig. 0,020. Berdasarkan nilai Sig. 0,05>0,020, $\mathrm{H}_{0}$ diterima dan $\mathrm{H}_{\mathrm{a}}$ ditolak sehingga koefisien analisis jalur tidak signifikan. Sehingga, motivasi belajar tidak berpengaruh pada hasil belajar. Kerangka hubungan kausal empiris antara $\mathrm{X}_{1}, \mathrm{X}_{2}$, dan $\mathrm{Z}$ terhadap $\mathrm{Y}$ dapat dibuat melalui persamaan struktural Model 2 sebagai berikut.

Struktur Model 2:

$Y=\beta_{3}+\beta_{4}+\beta_{5}+\varepsilon_{2}$

$\mathrm{Y}=0,330+0,308+0,195+0,429$

Nilai $\mathrm{R}_{\text {square }}$ tertera di tabel 4.13 Model Summary ${ }^{b}$. Guna memperoleh nilai $\varepsilon_{2}$ (variabel sisa) ditentukan dengan rumus berikut. Rumus: $\varepsilon_{2}=1-\mathrm{R}_{\text {square }}=1-0,571=0,429$. Sehingga dapat dilihat pada gambar 4 .

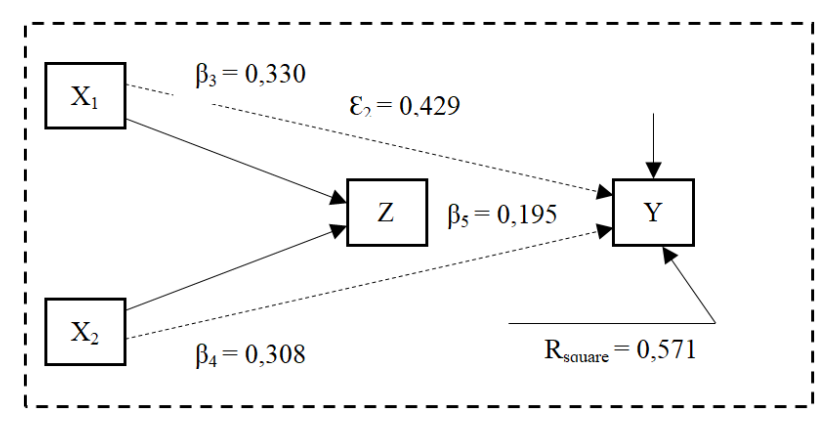

\section{Gambar 4. Diagram Jalur Kausal Empiris $X_{1}, X_{2}$, dan $Z$ terhadap Y Model 2}

Seseorang pelajar dengan motivasi yang baik akan memiliki kemauan yang besar untuk mempelajari sesuatu dengan baik pula. Hasil penelitian ini diperkuat oleh pendapat (Sardiman, 2004) menyatakan bahwa motivasi belajar yang tinggi dalam belajar akan memperlihatkan hasil yang baik. Riset oleh (Mappeasse, 2009) menyatakan bahwa ada dampak signifikan antara cara belajar dan motivasi belajar pada hasil belajar. Diperkuat riset (Puspitasari, Setyosari, \& Amirudin, 2016) dalam penelitiannya menyebutkan bahwa ada dampak yang signifikan motivasi belajar pada hasil belajar. Berdasarkan hasil analisis di atas, berikut adalah tabel hasil rangkuman perhitugan analisis jalur.

Tabel 8. Rangkuman Hasil Perhitungan Analisis Jalur

\begin{tabular}{clccc}
\hline Hipotesis & \multicolumn{1}{c}{ Pengaruh } & Koef. Jalur & t hit & Sig. \\
\hline 1 & Lingkungan Keluarga-Motivasi Belajar & 0.351 & 4.115 & 0.000 \\
2 & Fasilitas Belajar-Motivasi Belajar & 0.447 & 5.229 & 0.000 \\
3 & Lingkungan Keluarga-Hasil Belajar & 0.330 & 3.682 & 0.000 \\
4 & Fasilitas Belajar-Hasil Belajar & 0.308 & 3.332 & 0.001 \\
5 & Motivasi Belajar-Hasil Belajar & 0.195 & 2.346 & 0.020 \\
6 & Lingkungan Keluarga-Motivasi Belajar-Hasil Belajar & 0.068 & 1.991 & 0.049 \\
7 & Fasilitas Belajar-Motivasi Belajar-Hasil Belajar & 0.087 & 2.109 & 0.037 \\
\hline
\end{tabular}


Pada tabel 8, diketahui bahwa hasil pengujian pengaruh antara lingkungan keluarga pada motivasi belajar diperoleh nilai koefisien jalur $=0,351$, hasil pengujian pengaruh antara fasilitas belajar pada motivasi belajar diperoleh nilai koefisien jalur $=$ 0,447, hasil pengujian pengaruh antara lingkungan keluarga pada prestasi belajar diperoleh nilai koefisien jalur $=0,330$, hasil pengujian pengaruh antara fasilitas belajar pada prestasi belajar diperoleh nilai koefisien jalur $=0,308$, hasil pengujian pengaruh antara motivasi belajar pada prestasi belajar diperoleh nilai koefisien jalur $=0,195$. Sedangkan lingkungan keluarga pada prestasi belajar ditinjau dari motivasi belajar mempunyai nilai koefisien jalur $=0,068$, dan hasil pengujian pengaruh antara fasilitas belajar pada prestasi belajar ditinjau dari motivasi belajar didapatkan nilai koefisien jalur $=0,087$. Berdasarkan hasil output regresi model 1 dan 2, maka dapat dibuat analisis yang menjelaskan adanya pengaruh langsung dan tidak langsung pada variabel penelitian. Analisis tersebut dijabarkan sebagai berikut.

1. Pengaruh Langsung

a. Analisis pengaruh lingkungan keluarga $\left(\mathrm{X}_{1}\right)$ pada motivasi belajar $(\mathrm{Z})$ : dari hasil analisis $\mathrm{X}_{1}$ diperoleh nilai Sig. $0,000<0,05$, berarti secara langsung terdapat pengaruh yang signifikan antara $\mathrm{X}_{1}$ dan $\mathrm{Z}$.

b. Analisis pengaruh fasilitas belajar $\left(\mathrm{X}_{2}\right)$ pada motivasi belajar $(\mathrm{Z})$ : diketahui bahwa $\mathrm{X}_{2}$ diperoleh nilai Sig. $0,000<$ 0,05 , berarti ada pengaruh yang signifikan antara $\mathrm{X}_{2}$ dan $\mathrm{Z}$.

c. Analisis pengaruh fasilitas belajar $\left(\mathrm{X}_{2}\right)$ pada hasil belajar $(\mathrm{Y})$ : dari hasil analisis $\mathrm{X}_{2}$ diperoleh nilai Sig. 0,001, sehingga bisa dikatakan ada pengaruh yang signifikan antara $\mathrm{X}_{2}$ dan $\mathrm{Y}$.

d. Analisis pengaruh motivasi belajar (Z) pada hasil belajar (Y): hasil analisis Z diperoleh nilai Sig. 0,020, sehingga bisa dikatakan ada pengaruh yang signifikan antara $\mathrm{Z}$ dan $\mathrm{Y}$.

e.

2. Pengaruh Tidak Langsung

a. Analisis pengaruh tidak langsung lingkungan keluarga $\left(\mathrm{X}_{1}\right)$ pada prestasi belajar $(\mathrm{Y})$ ditinjau dari motivasi belajar (Z): untuk menghitung besarnya pengaruh $\mathrm{X}_{1}$ terhadap $\mathrm{Y}$ melalui $\mathrm{Z}$ dengan cara menjumlahkan hasil koefisien beta jalur $\mathrm{X}_{1}$ menuju $\mathrm{Y}$ dengan mengalikan koefisien beta jalur $\mathrm{X}_{1}$ menuju $\mathrm{Z}$ dengan koefisien beta jalur $\mathrm{Z}$ menuju $\mathrm{Y}$, yaitu $0,330+(0,351 \times 0,195)=0,330+0,068=0,398$. Oleh sebab itu, diperoleh pengaruh total $\mathrm{X}_{1}$ terhadap $\mathrm{Y}=$ 0,398 .

Analisis pengaruh tidak langsung fasilitas belajar $\left(\mathrm{X}_{2}\right)$ terhadap hasil belajar $(\mathrm{Y})$ ditinjau dari motivasi belajar $(\mathrm{Z})$ : cara yang dilakukan sama dengan yang sebelumnya, yaitu menjumlahkan hasil koefisien beta jalur $\mathrm{X}_{2}$ menuju $\mathrm{Y}$ dan mengalikan koefisien beta jalur $X_{2}$ menuju $Z$ dengan koefisien beta jalur $Z$ menuju $Y=0,308+(0,447 \times 0,195)=0,308+0,087=0,395$. Jadi, diperoleh pengaruh total $\mathrm{X}_{2}$ terhadap $\mathrm{Y}$ sebesar 0,395 .

\section{SIMPULAN}

Menurut hasil analisis dan pembahasan, bisa disimpulkan yakni (1) ada pengaruh langsung antara lingkungan keluarga pada motivasi belajar siswa di SMPN 1 Ngunut kabupaten Tulungagung. Hal tersebut berarti bahwa semakin bagus situasi suatu lingkungan keluarga siswa, maka semakin tinggi pula motivasi belajar siswa; (2) ada pengaruh langsung antara fasilitas belajar pada motivasi belajar siswa di SMPN 1 Ngunut kabupaten Tulungagung. Sehingga dapat dikatakan kelengkapan fasilitas belajar serta dengan pemanfaatan yang maksimal, maka akan menumbuhkan motivasi belajar pada siswa; (3) ada pengaruh langsung antara lingkungan keluarga pada prestasi belajar IPS siswa di SMP Negeri 1 Ngunut kabupaten Tulungagung. Hal tersebut berarti bahwa lingkungan keluarga yang kondusif bisa meningkatkan hasil belajar IPS siswa di sekolah; (4) ada pengaruh langsung antara fasilitas belajar pada prestasi IPS siswa di SMPN 1 Ngunut kabupaten Tulungagung. Hal tersebut berarti bahwa penyediaan fasilitas belajar yang lengkap, yang disertai dengan pemanfaatan fasilitas belajar secara maksimal, akan dapat mengoptimalkan prestasi yang dicapai oleh siswa; (5) ada pengaruh langsung antara motivasi belajar siswa pada prestasi belajar IPS siswa di SMP Negeri 1 Ngunut kabupaten Tulungagung. Berarti apabila siswa yang mempunyai motivasi belajar yang tinggi, berpengaruh pada prestasi belajar IPS yang optimal. Sebaliknya, apabila siswa mempunyai motivasi belajar yang rendah, prestasil belajar IPS yang didapatkan siswa rendah; (6) ada pengaruh tidak langsung antara fasilitas belajar pada prestasi belajar IPS yang ditinjau dari motivasi belajar siswa di SMP Negeri 1 Ngunut kabupaten Tulungagung. Hal tersebut berarti bahwa semakin baik motivasi belajar siswa, maka semakin besar pula pengaruhnya pada fasilitas belajar terhadap hasil belajar IPS siswa.

Saran yang dapat peneliti berikan yakni (1) bagi sekolah, melalui kebijakan-kebijakan yang telah diterapkan diharapkan mampu menciptakan dan mengatur kondisi dalam pembelajaran tetap kondusif sehinnga muncul kenyamanan belajar; (2) bagi guru, guru sebagai fasilitator sebaiknya bisa memanipulasi KBM yang baik bagi siswa. Guru bisa melaksanakn penggunaan metode yang bervariasi guna meningkatkan perhatian dan motivasi siswa dalam KBM; (3) bagi orangtua diharapkan dapat memberikan perhatian yang besar kepada anak dalam hal belajar, menciptakan lingkungan belajar yang baik dan memberikan fasilitas belajar yang memadahi guna membangkitkan motivasi belajar siswa dalam mencapai optimalisasi prestasi belajar; (4) bagi siswa, diharapkan mempunyai aturan belajar yang bagus dan mampu menggali serta meningkatkan motivasi belajarnya 
sendiri karena dengan kebiasaan belajar yang baik dan motivasi yang tinggi akan membuat siswa menjadi lebih cermat serta terarah saat KBM dan bisa meningkatkan prestasi belajar IPS; (5) bagi peneliti selanjutnya diharapkan mampu menambah variabel-variabel penelitiannya dan memperluas cakupan populasi yang akan digunakan dalam penelitian serupa.

\section{DAFTAR RUJUKAN}

Bafadal, I. (2008). Perlengkapan Sekolahan Motivasi Belajar terhadap Prestasi Belajar Mata Pelajaran Ekonomi Siswa Kelas XII IS di SMA Negeri 5 Surakarta Tahun Ajaran 2015/2016. Jurnal Pendidikan Bisnis dan Ekonomi, 1(2).

Dimyati, D., \& Mudjiono, M. (2010). Belajar dan Pembelajaran. Jakarta: Rineka Cipta.

Djamarah, S. B. (2014). Pola Asuh Orangtua dan Komunikasi Dalam Keluarga. Jakarta: Rineka Cipta.

Jamal, S. (2017). Pengaruh Motivasi Belajar terhadap Prestasi Belajar IPS Siswa Kelas VIII SMP N 2 Srumbung. Social Studies, 6(4), 469-479.

Jamil, H., \& Azra, F. I. (2014). Pengaruh Lingkungan Keluarga dan Motivasi Belajar Siswa terhadap Hasil Belajar Akuntansi Siswa Kelas X SMK Negeri 1 Solok Selatan. Journal of Economic and Economic Education Vol, 2(2), 85-98.

Mappeasse, M. Y. (2009). Pengaruh Cara dan Motivasi Belajar terhadap Hasil Belajar Programmable Logic Controller (PLC) Siswa Kelas III Jurusan Listrik SMK Negeri 5 Makassar. Jurnal Medtek, 1(2), 1-6.

Mega, E. (2017). Pengaruh Lingkungan Sekolah, Lingkungan Keluarga dan Fasilitas Belajar di Sekolah terhadap Motivasi Belajar Siswa pada Mata Pelajaran IPS Terpadu Kelas VIII SMP Negeri 2 Linggo Sari Baganti Kabupaten Pesisir Selatan. Skripsi tidak diterbitkan. STKIP PGRI Sumatera Barat.

Novalinda, E., Kantun, S., \& Widodo, J. (2017). Pengaruh Motivasi Belajar terhadap Hasil Belajar Mata Pelajaran Akuntansi Siswa Kelas X Jurusan Akuntansi Semester Ganjil SMK PGRI 5 Jember Tahun Pelajaran 2016/2017. Jurnal Pendidikan Ekonomi, 115.

Prihatin, M. S. (2017). Pengaruh Fasilitas Belajar, Gaya Belajar dan Minat Belajar terhadap Hasil Belajar Mata Pelajaran Ekonomi Siswa Kelas X IIS SMA Negeri 1 Seyegan. Jurnal Pendidikan dan Ekonomi, 6(5), 443-452.

Purwanto, N. (2014). Psikologi Pendidikan. Bandung: Remaja Rosdakarya.

Puspitasari, E., Setyosari, P., \& Amirudin, A. (2016). Peningkatan Motivasi dan Hasil Belajar melalui Think Pair Share (TPS) di Sekolah Dasar. Jurnal Pendidikan: Teori, Penelitian, dan Pengembangan, 1(7), 1432-1436.

Puspitasari, W. D. (2016). Pengaruh Sarana Belajar terhadap Prestasi Belajar Ilmu Pengetahuan Sosial di Sekolah Dasar. Jurnal Cakrawala Pendas, 2(2).

Rachmah, L. L., Sunaryanto, S., \& Yuniastuti, Y. (2019). Pengaruh Lingkungan Keluarga, Fasilitas Belajar pada Prestasi Belajar IPS Siswa Ditinjau dari Motivasi Belajar. Jurnal Pendidikan: Teori, Penelitian, dan Pengembangan, 4(9), 11681176.

Rahman, M. F. (2015). Pengaruh Dukungan Orangtua dan Fasilitas Belajar di Sekolah terhadap Prestasi Belajar Ekonomi Melalui Motivasi Belajar Siswa Kelas VIII SMP Negeri 2 Ungaran. Prosiding Seminar Pendidikan Ekonomi dan Bisnis, $1(1)$.

Rohman, A., \& Lamsuri, M. (2009). Memahami Pendidikan dan Ilmu Pendidikan. LaksBang Mediatama bekerja sama dengan Kantor Advokat" Hufron \& Hans Simaela".

Sari, W. P. (2005). Pengaruh Fasilitas Belajar terhadap Hasil Belajar Komputer Siswa Kelas II Program Keahlian Sekretaris di SMK Batik 1 Surakarta. Skripsi tidak diterbitkan. Universitas Negeri Semarang, Semarang.

Slameto, S. (2015). Belajar dan Faktor-faktor yang Memengaruhi. Jakarta: Rineka Cipta.

Sugiyanto, S. (2015). Pengaruh Fasilitas Belajar, Lingkungan Keluarga, dan Lingkungan Sosial terhadap Hasil Belajar IPS. Seminar Nasional Universitas PGRI Yogyakarta 2015, 72-79.

Supardan, D. (2015). Pembelajaran Ilmu Pengetahuan Sosial: Perspektif Filosofi dan Kurikulum. Jakarta: PT Bumi Aksara.

Suwardi, D. R. (2012). Faktor-Faktor yang Memengaruhi Hasil Belajar Siswa Kompetensi Dasar Ayat Jurnal Penyesuaian Mata Pelajaran Akuntansi Kelas XI IPS di SMA Negeri 1 Bae Kudus. Economic Education Analysis Journal, 1(2), 1-7.

Yonitasari, D. (2014). Pengaruh Cara Belajar, Lingkungan Keluarga, dan Fasilitas Belajar terhadap Prestasi Belajar Ekonomi Akuntansi Siswa Kelas XI IPS SMA Negeri 4 Magelang Tahun Ajaran 2013/2014. Economic Education Analysis Journal, 3(2), 241-248. 